\title{
Zdolność do identyfikacji emocji na podstawie ekspresji mimicznych - doniesienie z badań przestępców
}

\author{
Jakub Knecht ${ }^{1}$ \\ jakub.knecht@gmail.com \\ Uniwersytet im. Adama Mickiewicza \\ w Poznaniu
}

\begin{abstract}
Artykuł jest raportem $\mathrm{z}$ badań nad związkiem inteligencji emocjonalnej z objawami psychopatologicznymi u osób skazanych wyrokami sądu na odbywanie kar w zakładzie zamkniętym. Przeprowadzone badania miały na celu udzielenie odpowiedzi na pytanie czy poziom inteligencji emocjonalnej osób skazanych różni się $\mathrm{W}$ porównaniu $\mathrm{z}$ nieskazanymi. Uczestnikami badania było 50 przestępców odbywających karę w Zakładzie Karnym nr 1 we Wrocławiu. Do pomiaru zmiennych zastosowano następujące narzędzia: kwestionariusz Symptom Checklist-90 oraz Skalę Inteligencji Emocjonalnej - Twarze. Wyniki badania wykazały, że nie istnieje związek miedzy objawami psychopatologicznymi a inteligencją emocjonalną u skazanych. Raport stanowi próbę wyjaśnienia otrzymanych wyników.
\end{abstract}

\section{Wprowadzenie teoretyczne}

Zgodnie $\mathrm{z}$ polskim prawem skazany to osoba fizyczna, którą sąd w postępowaniu karnym, prawomocnym wyrokiem lub nakazem karnym, uznał winną popełnienia przestępstwa i wymierzył karę lub środek karny (1997, Kodeks karny wykonawczy, art. 5). Jest to definicja prawna. Za definicję psychologiczną niech posłuży ta sformułowana przez Gierowskiego (2005, s. 712) iż: ,przestępca to człowiek, który ze względu na swoje właściwości osobowościowe oraz sytuację, w jakiej się znajdował, uruchomił motywację prowadzącą do celu, który nie jest społecznie akceptowany i jest prawnie zabroniony". Gierowski (tamże) powołując się na badania i eksperymenty ostatnich lat wyodrębnia cztery podstawowe czynniki biopsychiczne, których określone natężenie, lub jedynie wystąpienie,

\footnotetext{
${ }^{1}$ Raport z badania został napisany na podstawie pracy magisterskiej pt. „Analiza związku psychotyczności z umiejętnością rozpoznawania emocji u osób skazanych”, napisanej w Instytucie Psychologii UAM pod kierunkiem dr Aleksandry Jasielskiej i recenzowanej przez prof. dr hab. Władysława Jacka Paluchowskiego.
} 
może mieć wpływ na popełnienie czynu przestępczego, czyli stanie się przestępcą. Są to: charakteropatia, temperament, psychopatia i inteligencja.

Charakteropatia rozumiana jest jako specyficzny zespół cech osobowości, charakterystyczny dla jednostek, u których stwierdza się zmiany $\mathrm{w}$ strukturze i funkcjonalnych właściwościach ośrodkowego układu nerwowego. Zmiany te najczęściej spowodowane są działaniem szkodliwego, uszkadzającego bodźca. Charakteropatia, w postaci zmian osobowości typu psychopatycznego wyrażających się w odchyleniach charakterologicznych, przejawia się u przestępców poprzez uksztaltowanie się indywidualnego systemu wartości. Przykładowym systemem jest taki, który nie uwzględnia dobra innych ludzi, a jeśli uwzględnia, to jedynie osób z własnego kręgu rodzinnego lub koleżeńskiego (Błachut, Gaberle, Krajewski, 2007).

W badaniach nad temperamentem przestępców, rozumianym jako szczególny zespó 1 właściwości układu nerwowego, zwraca się uwagę na pewne cechy, które przy prawidłowo funkcjonującym układzie nerwowym, mogą sprzyjać niewłaściwym formom zachowania, w tym przestępczym. W tym obszarze Eysenck (1964, za: Gierowski, 2005) wskazał poziom ekstrawersji i neurotyczności - podstawowych w jego teorii wymiarów osobowości. Eysenck (tamże) sugeruje, że poprawna socjalizacja jednostki, czyli nabycie i utrwalenie odruchów warunkowych właściwych społeczeństwu, umożliwi unikanie przez tę jednostkę zachowań antyspołecznych, w tym przestępczych. U ekstrawertyków warunkowanie jest trudniejsze, a u introwertyków łatwiejsze, co nie pozostaje bez wpływu na kształtowanie się zachowań antyspołecznych. Istotną rolę $\mathrm{w}$ socjalizacji odgrywa wrażliwość emocjonalna, mająca podłoże biologiczne określana jako neurotyczność. Niski stopień neurotyczności oznacza zrównoważenie emocjonalne, odporność na stres i reakcje adekwatne do bodźca, a wysoki odwrotność wymienionych cech. Wysoka neurotyczność wpływa negatywnie na socjalizację. Wniosek Eysencka (1964, za: Błachut, Gaberle, Krajewski, 2007) jest taki, że ekstrawertyzm połączony z wysokim neurotyzmem utrudniają utrwalenie odruchów pozwalających na unikanie zachowań antyspołecznych ( $w$ tym przestępczych).

Z kolei, psychopatia jest nazwą ogólną dla szeregu dyspozycji psychicznych, charakterologicznych i temperamentalnych cech, które określa się jako psychopatyczne głównie za względu na ich natężenie i wzajemne relacje. Psychopatyczność polega nie tyle na wykazywaniu zachowań niestandardowych, co na intensywności zachowań właściwych osobom pełnowartościowym pod względem psychicznym (Schneider, 1934 za: Batawia, 1984). Jako charakterystykę psychopatyczności określa się niezdolność do trwałych 
związków uczuciowych, spowodowaną upośledzeniem sfery uczuciowości wyższej i związaną z tym przewagę sfery popędowo - emocjonalnej nad wyższymi poziomami regulacji. Prowadzi to do zachowań impulsywnych, kiedy zawodzą mechanizmy regulacyjne zachowania, co nie zawsze wiąże się z obniżeniem inteligencji. Możliwe jest wtedy kalkulowanie opłacalności określonego zachowania (Błachut, Gaberle, Krajewski, 2007) i niejako używanie tego zaburzenia w celach przestępczych.

Kwestię inteligencji u przestępców podnieśli Herrnstein i Murray (1994). Według wspomnianych autorów wysoki poziom inteligencji, pozostaje $\mathrm{w}$ związku $\mathrm{z}$ wysokimi zarobkami $\mathrm{i}$ powodzeniem $\mathrm{W}$ pracy, natomiast niski $\mathrm{z}$ ciążami pozamałżeńskimi, długotrwałym pozostawaniem na utrzymaniu pomocy społecznej i skłonnością do przestępczości. Stwierdzili także, że iloraz inteligencji przeważa nad oddziaływaniem statusu socjoekonomicznego rodziców czy ich wykształceniem. Wysoka inteligencja jest swego rodzaju ochroną przed przestępczością. Osoby wychowujące się w patologicznych domach, których rodzice byli kryminalistami, są bardziej odporne na zostanie przestępcami, jeżeli ich inteligencja jest wysoka. Natomiast jeżeli ich IQ jest niskie ryzyko poddania się tego rodzaju wpływom jest większe.

Należy zaznaczyć, co podnosi Gierowski (2005), że badania nad kryminogenną rolą czynników biopsychologicznych nie doprowadziły do ustalenia tezy, że wystąpienie któregokolwiek z wymienionych czynników, szczególnie w sytuacji, gdy odbiega on od przyjętej normy, wystarcza lub jest konieczne do pojawienia się zachowania przestępczego. Wskazuje on jednak na badania, które pozwalają stwierdzić, że każdy z czynników może powodować wystąpienie zachowań przestępczych jeśli dołączą do niego dodatkowe okoliczności. Zmiennym biopsychicznym można zatem przypisać charakter czynnika fragmentarycznego, pozwalającego jednie w niewielkim stopniu odpowiedzieć na psychologiczne uwarunkowania przestępczości Wydaje się słusznym zatem wskazanie jeszcze jednego czynnika mającego wpływ na właściwości osobowościowe, spoza kręgu czynników biopsychicznych, a mianowicie wpływ środowiska zewnętrznego.

Omówione powyżej czynniki biopsychiczne mają wpływ na właściwości osobowościowe przestępcy. Wyróżnienie powyższych teoretycznych dymensji pozwalających różnicować przestępców od nie przestępców w niewielkim stopniu przekłada się na praktykę badawczą. Kosewscy (1976, za: Shuessler, 1960) twierdzą, że w większości wyniki badań psychologicznych nie pozwalają odróżnić przestępców od nie przestępców na podstawie cech czy ich charakterystyki. 
Kosewski i Kosewska (1976) zbadali także czy da się różnicować populację przestępczą od nie przestępczej pod względem agresywności. W badaniu tym uchwycono różnice w wyuczonych społecznie sposobach przejawiania agresji, a nie w ogólnym poziomie agresywności rozumianym jako skłonność do częstszych reakcji agresywnych.

Również Gierowski (2005) twierdzi, że nie ma tu prostej zależności pomiędzy właściwościami temperamentalnymi a tendencją do łamania prawa. Zależności o takim charakterze można zauważyć, dopiero, gdy wprowadzi się typologie sprawców, uwzględniającą charakter popełnianych czynów, ich okoliczności, i zmienne motywacyjne.

Z powyższych danych wynika, że pula cech podmiotowych opisujących funkcjonowanie psychiczne przestępców jest niezwykle różnorodna. Taki stan rzeczy zachęca do poszukiwania kolejnych, możliwych cech współwystępujących z przestępczością, które byłyby możliwe do zaobserwowania i porównania np. w warunkach więziennych. Mogłyby to być cechy, na których temat skazani byliby skłonni ujawnić autentyczne informacje, a najlepiej, gdyby byli do tego zmotywowani, oraz byliby w stanie sprostać wymaganiom udziału w badaniach. Punktem wyjścia były cechy określane jako psychopatyczne. Za Gierowskim (2005, s. 717) są to:

- skłonności do zachowań charakteryzujących się nagłymi wybuchami i niekontrolowaną agresją,

- nieliczenie się ze skutkami własnego postępowania,

- brak zdolności w nawiązywaniu bliskich związków uczuciowych z innymi ludźmi,

- deficyt poczucia lęku,

- zwiększone zapotrzebowaniem na stymulację.

Choć nie wyjaśniono jednoznacznie etiologii psychopatii, a wśród badaczy nie ma zgody co do jej definicji, czy istoty, to zauważalne jest, że cechy określane jako psychopatyczne wiążą się $\mathrm{z}$ dysfunkcją w zakresie przetwarzania emocji. Aktualnie na gruncie psychologii emocji dyskutowana jest stosunkowo nowa koncepcja inteligencji emocjonalnej. (Mayer, Salovey, Caruso, 2004). Model inteligencji emocjonalnej (Matczak, Piekarska, Studniarek, 2005), zakłada, że zdolności emocjonalne tworzą cztery poziomy:

1) Zdolność do percepcji, oceny i wyrażania emocji,

2) Emocjonalne wspomaganie myślenia (określane też jako zdolność do asymilowania emocji w przebiegu procesów poznawczych),

3) Rozumienie i analizowanie emocji,

4) Kontrolowanie i świadome regulowanie emocji. 
Ze względu na specyfikę omawianej grupy podjęto decyzję, że badaniami zostanie objęty pierwszy z wymienionych poziomów, utożsamiany z umiejętnością rozpoznawania emocji, która w koncepcji Mayera, Saloveya i Caruso (tamże), traktowana jako rodzaj zdolności poznawczych jest wyznacznikiem inteligencji emocjonalnej.

Zdolność do spostrzegania emocji jest podstawową i uniwersalną właściwością emocjonalną włączoną w model inteligencji emocjonalnej, która obejmuje takie specyficzne umiejętności jak, m. in. zdolność do identyfikowania emocji u innych osób, ale także u siebie na podstawie wyglądu czy tonu głosu (tamże).

Zgodnie z koncepcją inteligencji emocjonalnej (tamże, s. 13) twarz drugiej osoby sygnalizuje jej stany wewnętrzne: komunikuje emocje, zarówno świadomie, jak i nieświadomie. Ekman (2003) udowodnił, że ludzka twarz dostarcza więcej niż jeden rodzaj sygnałów, które służą do przekazania wielu rodzajów informacji o emocjach. Mylne rozpoznanie może wynikać z wielu czynników takich jak np. niewłaściwe rozróżnianie informacji o mimicznym wskazaniu emocji. Trafne rozpoznawanie (Matczak, Piekarska, Studniarek, 2005) ma duże znaczenie dla efektywnego funkcjonowania społecznego człowieka, a fakt występowania różnic indywidualnych w zakresie rozpoznawania umożliwia pomiar wysokości inteligencji emocjonalnej u poszczególnych osób. Prawdopodobne zatem jest, że osoby przebywające w zakładzie karnym posiadają niższy poziom dostosowania społecznego, który może z kolei być związany $\mathrm{z}$ obniżoną inteligencją emocjonalną i precyzyjniej rzecz ujmując, obniżoną zdolnością do spostrzegania ekspresji mimicznej innych osób. Przyjęto zatem hipotezę, że zdolność rozpoznania ekspresji mimicznej emocji w grupie osób skazanych będzie niższa, niż w grupie osób nieskazanych.

\section{Badania wlasne}

\section{Metoda}

W badaniu wykorzystano narzędzie Skala Inteligencji Emocjonalnej - Twarze autorstwa Matczak, Piekarskiej i Studniarek (2005). Jest to test służący do pomiaru zdolności do rozpoznawania ekspresji mimicznej (Matczak, Piekarska, Studniarek, 2005). Test składa się z zeszytu testowego oraz arkusza odpowiedzi. Materiał testowy stanowi 18 fotografii twarzy. Twarze przedstawione na zdjęciach wyrażają osiem pozytywnych stanów emocjonalnych (cztery przez mężczyznę i cztery przez kobietę) i 10 negatywnych stanów emocjonalnych (pięć przez kobietę i pięć przez mężczyznę). Każdej z fotografii jest 
przypisany (na arkuszu odpowiedzi) inny zestaw sześciu nazw emocji, wśród których znajdują się zarówno emocje pozytywne jak i negatywne.

Badany ma zdecydować, czy widoczna na fotografii twarz wyraża wymienione emocje, i każdorazowo zaznaczyć jedną z trzech możliwych odpowiedzi: „wyraża”, „nie wyraża”, „trudno powiedzieć”. W instrukcji zaznaczono, by z ostatniej możliwości korzystać tylko w wyjątkowych przypadkach. Zadania właściwe poprzedzone są przykładem, w którym w stosunku do dwu emocji poprawna jest odpowiedź ,wyraża”, a w stosunku do pozostałych czterech - odpowiedź „nie wyraża”.

Każda nazwa emocji stanowi odrębny odrębną pozycję testową, łączna liczba pozycji wynosi 108 (18 fotografii x 6 nazw emocji przypisanych każdej fotografii). Zgodnie z kluczem odpowiedzi „trudno powiedzieć” nigdy nie są poprawne. Liczba emocji, w odniesieniu do których poprawna jest odpowiedź „wyraża”, waha się w zależności od fotografii od jednej (tylko na jednym zdjęciu) do czterech. W pozostałych przypadkach poprawne są odpowiedzi ,nie wyraża”. Za każdą poprawną odpowiedź badany uzyskuje 1 punkt. Maksymalny możliwy wynik testu wynosi 108 punktów.

$\mathrm{Na}$ podstawie wyników prób normalizacyjnych dla testu SIE-T obliczono współczynniki zgodności wewnętrznej (alfa Cronbacha). Współczynniki w większości osiągnęły wartości wyższe niż 0,80 - można zatem stwierdzić, że rzetelność testu jest stosunkowo wysoka. Również współczynniki korelacji r Pearsona między wynikami SIE-T, a innymi testami służącymi do pomiaru inteligencji emocjonalnej lub komponentów inteligencji emocjonalnej, okazały się istotne statystycznie w większości badanych grup. Wyjątkiem była grupa uczniów liceów, gdzie wyniki okazały się nieistotne statystycznie. Dla pozostałych grup współczynnik r Pearsona osiągnął wartość najniższą dla wyników korelacji SIE-T z TRE w grupie studentów, gdzie wartość wyniosła $r=0,22$, do wartości najwyższej dla wyników korelacji SIE-T z MEIS w grupie osób dorosłych, gdzie wartość wyniosła r=0,42 (Matczak, Piekarska, Studniarek, 2005). Wyżej wskazane wyniki pozwalają stwierdzić, iż test SIE-T jest trafny jako narzędzia służące do badania zdolności do rozpoznawania emocji, będącej komponentem inteligencji emocjonalnej.

W badaniu użyto również kwestionariusza SCL-90. Narzędzie Symptom Checklist 90 (SCL-90) (Włodawiec, 2013) jest wystandaryzowanym narzędziem pomiaru efektywności psychoterapii, umożliwiającym stosowanie w szerokim zakresie, wobec różnych grup pacjentów i mierzącym szerokie aspekty zmiany 
Kwestionariusz SCL-90 mierzy nasilenie objawów psychopatologicznych, na które często uskarżają się pacjenci poszukujący pomocy psychoterapeutycznej i psychiatrycznej. Narzędzie składa się z 90 pozycji, odnoszących się do dziewięciu podstawowych zespołów objawów, które tworzą 9 następujących skal: 1) somatyzacja, 2) natręctwa, 3) nadwrażliwość interpersonalna, 4) depresja, 5) lęk, 6) wrogość, 7) fobie, 8) myślenie paranoidalne, 9) psychotyczność.

Całość składa się z 90 pytań na temat dolegliwości i problemów, na których stopień odczuwania osoba badana ma wskazać: wcale, nieznacznie, umiarkowanie, znacznie, lub bardzo silnie. Odpowiedzi są punktowane w skali od 0 do 3, gdzie wcale oznacza 0 , natomiast bardzo silnie oznacza 3. Każdej skali odpowiadają określone pytania, których numery zaprezentowane są w tabeli nr 2. Punkty są sumowane w obrębie skali, do której przynależą pytania. Maksymalny możliwy wynik stanowi za każdym razem ilość pytań przynależących do skali pomnożone przez 3.

Należy tu wspomnieć, że w ramach prowadzonych badań skazani wypełniali wyżej wymieniony kwestionariusz w celu ustalenia, czy w próbie znajdują się osoby wykazujące objawy psychopatologiczne. Celem pracy było przede wszystkim ustalenie czy istnieje związek, a jeśli tak, to jaki jest charakter związku między objawami, a inteligencją emocjonalną. Ponieważ związku nie zaobserwowano - wyniki uzyskane kwestionariuszem w tym opracowaniu nie są przytaczane.

\section{Procedura badania}

Uczestnikami badania było 50 przestępców odbywających wyroki w Zakładzie Karnym nr 1 we Wrocławiu przy ul. Kleczkowskiej 5. W badaniu udział wzięli wyłącznie mężczyźni w wieku od 19 do $56(\mathrm{M}=29,13$; SD =8,81). Z informacji sporządzonej przez pracownika Zakładu Karnego na podstawie akt skazanych wynika, że badani byli skazani za takie przestępstwa jak: rozbój, kradzież, pobicie, gwałt, oszustwo, udział w zorganizowanej grupie przestępczej, stręczycielstwo, zmuszanie do innych czynności seksualnych małoletniego czy znęcanie się na rodziną.

Rekrutacja osób do badania odbywała się w ten sposób, że w kolejnych celach badacz informował osadzonych o badaniach, ich czasochłonności oraz konieczności wyrażenia pisemnej zgody na udział. Zainteresowanie udziałem było znaczne - najczęściej zgodę wyrażała większość skazanych z jednej celi, często cała cela. W celach grypsujących zainteresowanie udziałem $\mathrm{w}$ badaniach było bliskie zeru - w jednym tylko przypadku cała 
cela grypsująca zadeklarowała chęć pobrania jednego kompletu kwestionariuszy bez wskazania który ze skazanych je wypełni. Po wydaniu kwestionariusza nigdy nie otrzymano go z powrotem, także nikt z celi nie zgłosił się na badanie Skalą Inteligencji Emocjonalnej. Badani dysponowali dużą ilością czasu do zagospodarowania, którą chętnie poświęcali na udział w badaniach. Jednak jeśli pojawiała się możliwość udziału w ciekawszych czynnościach więziennych takich jak fryzjer, możliwość skorzystania $\mathrm{z}$ aparatu telefonicznego, tzw. „wypiska” - czyli zakupy w sklepie więziennym, badani potrafili bez słowa zrezygnować $\mathrm{z}$ udziału $\mathrm{w}$ badaniach. Badani podporządkowywali się rygorowi przeprowadzanych badań i jeśli zdecydowali się wziąć udział w badaniach wypełniali kwestionariusz i test ze starannością.

Do badania przystąpiło 64 ochotników, którzy przed rozpoczęciem badań zostali poinformowani, iż uzyskane wyniki zostaną wykorzystane wyłącznie do celów badawczych pracy. Musieli wypełnić pisemną zgodę na udział w badaniach. By zachować anonimowość badań, po wypełnieniu zgody, nadawano im numer, którym posługiwali się wypełniając test i kwestionariusz, a także metryczkę. Badanie zostało podzielone na dwa etapy: w pierwszym etapie skazani byli zapoznawani $\mathrm{z}$ ofertą udziału w badaniach, informacją o celu badania i jego czasochłonnością. Jeśli wyrazili zgodę na udział w badaniach, otrzymywali komplet dokumentów w postaci dokumentu zgody na udział w badaniach, metryczki oraz kwestionariusza SCL-90. Jeżeli powyższe dokumenty zostały wypełnione, skazani byli przyprowadzani przez oddziałowego po trzech do osobnej sali gdzie wypełniali Skalę SIE-T. Wypełnianie testu było poprzedzone zebraniem zgody na udział w badaniu, metryczki, wypełnionego kwestionariusza SCL-90 oraz dodatkowym objaśnieniem instrukcji przez badającego. Gdy badani wypełniali test, badający sprawdzał poprawność wypełnionych dokumentów i w razie potrzeby skazani uzupełniali braki. Łączny czas jednego badania został oszacowany na około 60 minut, o czym badani zostali poinformowani. Po przebadaniu 64 osób, wyniki 14 uczestników badania zostały usunięte z różnych przyczyn. Najczęściej była to niemożność przebadania testem SIE-T, spowodowana przeniesieniem na inny oddział i trudnościami organizacyjnymi w dotarciu do skazanego, przeniesieniem do innego zakładu, lub zakończeniem odbywania kary. Średnio wypełnienie test zajmowało skazanym 15 minut, w przypadku najszybszym było to 10 minut, najdłużej test był wypełniany godzinę. Przebieg prowadzonych badań obrazuje tabela 1 . 
Tabela.1. Opis przebiegu zrealizowanych badań.

\begin{tabular}{|l|l|}
\hline Etap & Przebieg \\
\hline $\begin{array}{l}\text { 12.05.2013 Uregulowanie statusu prawnego } \\
\text { badacza na terenie Zakładu Karnego }\end{array}$ & $\begin{array}{l}\text { Skierowanie podania do Zakładu Karnego } \\
\text { nr 1 o możliwość przeprowadzenia badań }\end{array}$ \\
\hline $\begin{array}{l}28.05 .2013-\text { Przygotowania i pierwsze } \\
\text { badania }\end{array}$ & $\begin{array}{l}\text { Ustalenia zasad prowadzenia badań } \\
\text { z administracją Zakładu Karnego, Rekrutacja } \\
\text { części ochotników, Rozdanie i zebranie } \\
\text { części zgód na udział w badaniach, } \\
\text { metryczek i kwestionariuszy SCL-90, } \\
\text { przeprowadzenie badań Skalą Inteligencji } \\
\text { Emocjonalnej-Twarze }\end{array}$ \\
\hline 29.05 .2013 - Kontynuacja badań & $\begin{array}{l}\text { Rozdanie i zebranie części zgód na udział } \\
\text { w badaniach, metryczek i kwestionariuszy } \\
\text { SCL-90, przeprowadzenie kilku badań Skalą } \\
\text { Inteligencji Emocjonalnej - Twarze, } \\
\text { Przesunięcia administracyjne części } \\
\text { więźniów, którzy wypełnili kwestionariusz } \\
\text { SCL-90 uniemożliwiające zbadanie ich Skalą } \\
\text { Inteligencji Emocjonalnej-Twarze. }\end{array}$ \\
\hline 05.05 .2013 - Zakończenie badań & $\begin{array}{l}\text { Rozdanie i zebranie części zgód na udział } \\
\text { w badaniach, metryczek i kwestionariuszy } \\
\text { SCL-90, przeprowadzenie ostatnich badań } \\
\text { Skalą Inteligencji Emocjonalnej - Twarze. } \\
\text { Zakończenie Badań. }\end{array}$ \\
\hline
\end{tabular}

\section{Uzyskane wyniki}

Średnia liczba punktów uzyskanych podczas pomiaru zdolności do rozpoznawania ekspresji mimicznej za pomocą SIE-T wyniosła 56,72. Najniższy uzyskany wynik to 12 punktów zaś wynik najwyższy to 89. Wykres częstości dla skali charakteryzuje się lewostronną skośnością i wynosi -0,86. Wartość kurtozy wyniosła 0,10 - rozkład jest leptokurtyczny. Rozkład wyników pomiaru zdolności do rozpoznawania ekspresji mimicznej przedstawia rysunek nr 1 .

Średnie wyników w poszczególnych pozycjach testowych, uzyskanych w trakcie pomiaru zdolności do rozpoznawania ekspresji mimicznej za pomocą testu SIE-T, wynosiły od 2,42 do 4,08. Średnie wyniki pomiaru zdolności do rozpoznawania ekspresji mimicznej dla poszczególnych pytań przedstawia poniższy rysunek nr 2 . 


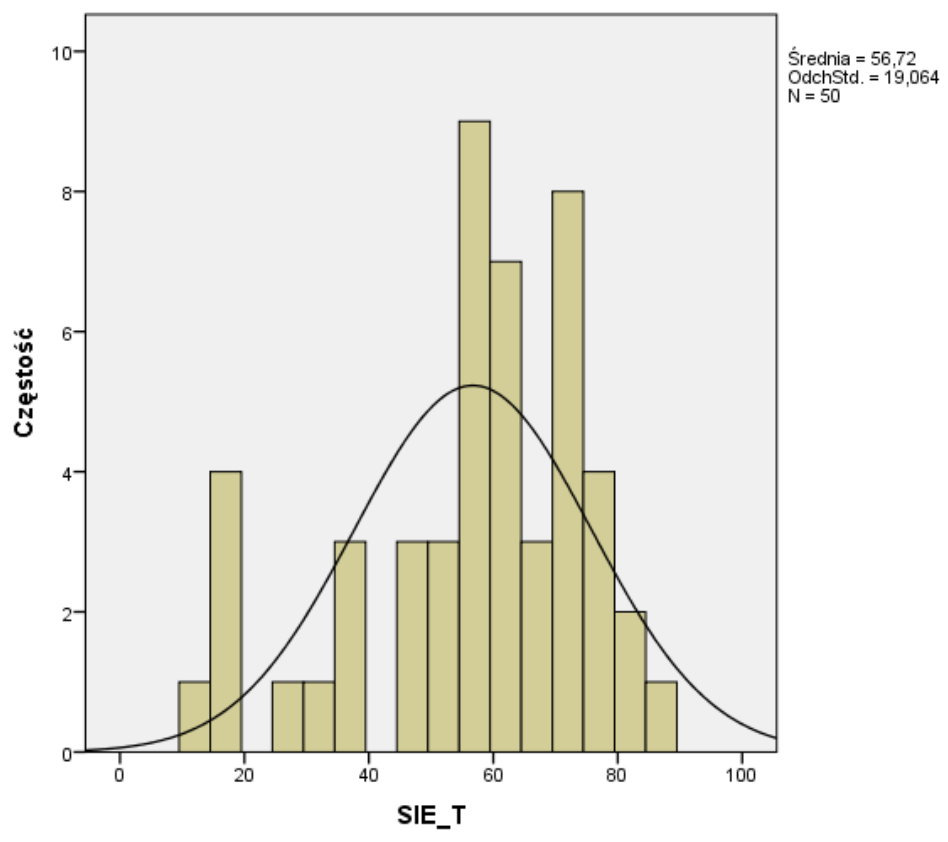

Rys. 1. Rozkład wyników pomiaru zdolności do rozpoznawania ekspresji mimicznej.

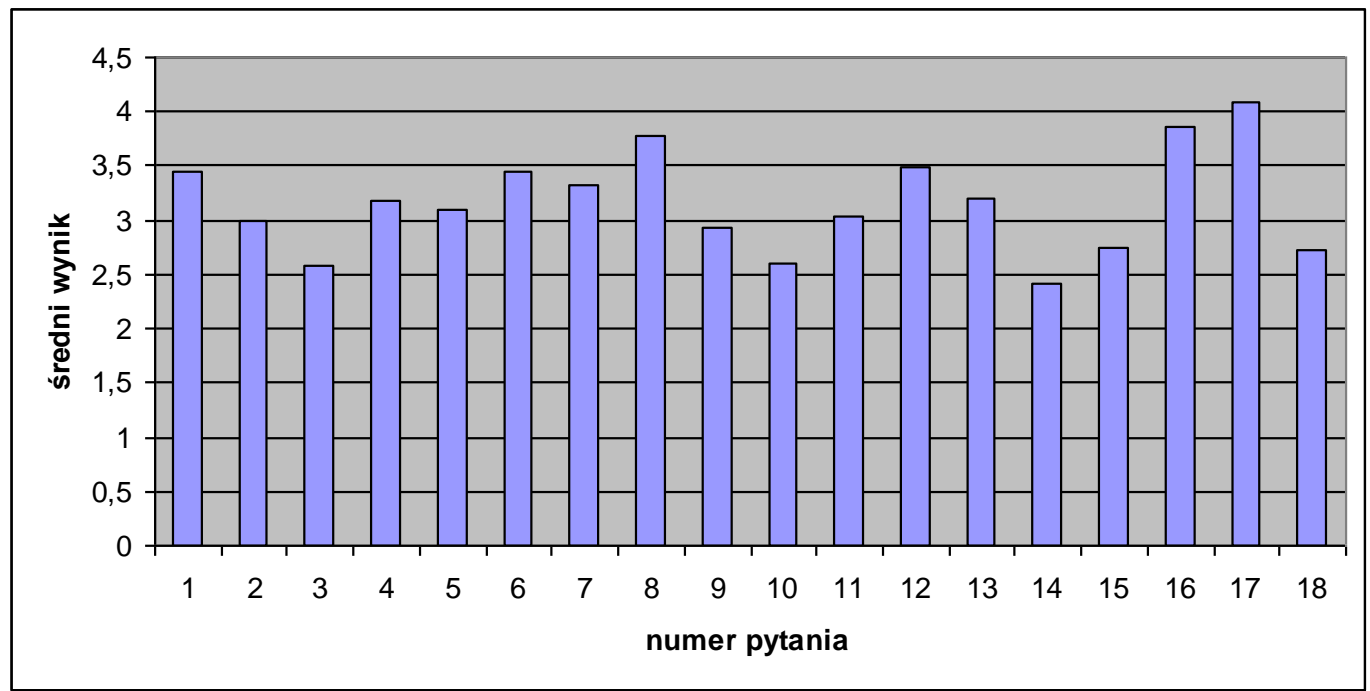

Rys. 2. Średnie wyników w poszczególnych pozycjach testowych uzyskanych w wyniku pomiaru zdolności do rozpoznawania ekspresji mimicznej.

W celu weryfikacji hipotezy mówiącej o różnicy w poziomie inteligencji emocjonalnej skazanych i nieskazanych przeprowadzono test t-Studenta dla jednej próby. Średni poziom inteligencji emocjonalnej mężczyzn, badanych testem SIE-T, w populacji mężczyzn wynosi $\mathrm{M}=74,5$ (Matczak, Piekarska, Studniarek, 2005). Wyniki otrzymane w przeprowadzonych badaniach odniesiono do tego wyniku. Analiza testem t-Studenta dla jednej próby wykazała, 
że w badanej próbie rozpoznanie ekspresji mimicznej emocji przez osoby skazane $(\mathrm{M}=56,72$; $\mathrm{SD}=19,06)$ jest istotnie statystycznie niższe od rozpoznanie ekspresji mimicznej emocji przez osoby nie będące skazanymi $t(49)=6,59 ; \mathrm{p}<0,01$. Powyższe dane obrazuje rysunek $\mathrm{nr} 3$.

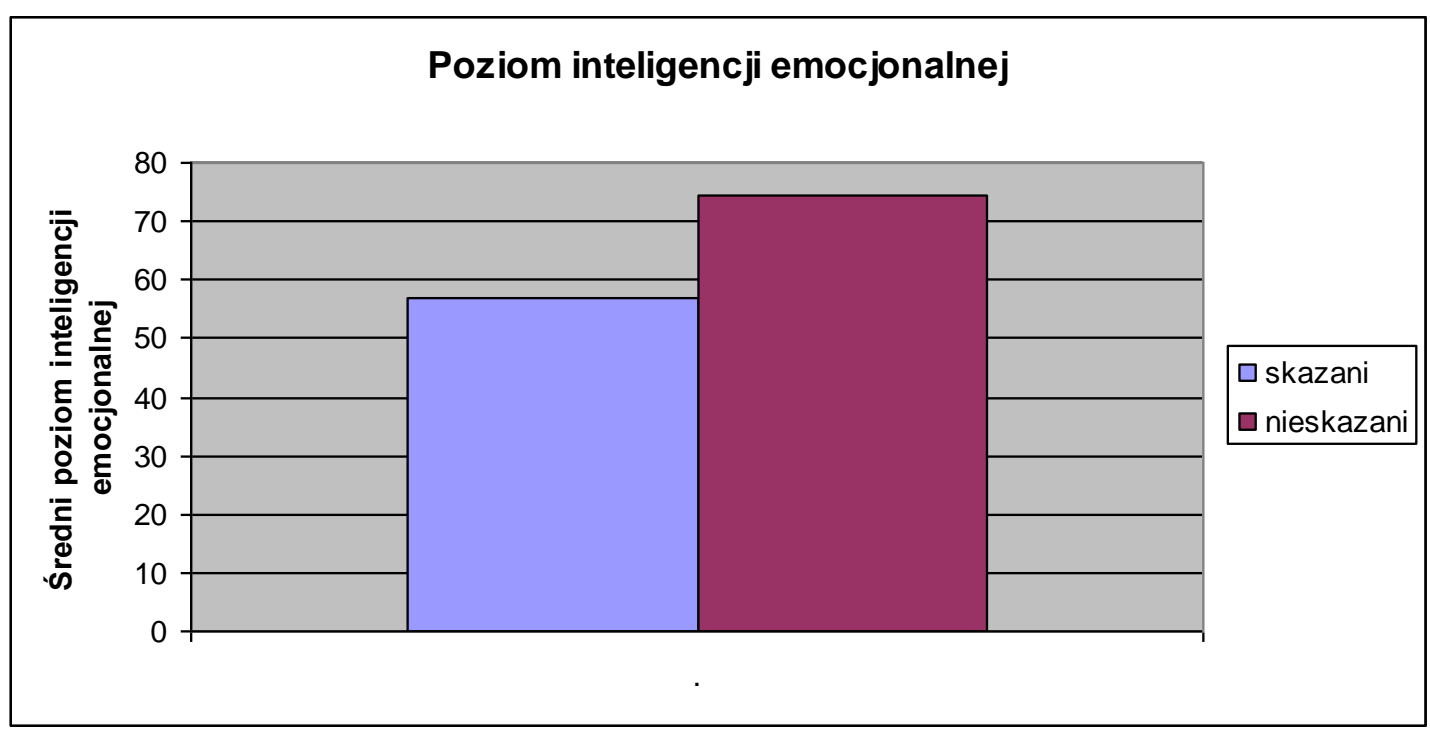

Rys. 3 Porównanie wyników inteligencji emocjonalnej skazanych i nieskazanych

\section{Dyskusja}

Potwierdzenie hipotezy, iż istnieje różnica w poziomie inteligencji emocjonalnej skazanych i nieskazanych może wskazywać na związek defektu kompetencji emocjonalnej ze skłonnością do przestępczości. Wyniki osób skazanych okazały się istotnie niższe od wyników osób nieskazanych, a ustalenia na które powołują się Iria i Bartosa (2009) wskazują, że przetwarzanie informacyjne emocji ma podstawowe znaczenie w społecznych interakcjach. Agresywne i impulsywne zachowanie, związane z defektem przetwarzania emocjonalnego nierzadko spełniają warunki popełnienia przestępstwa.

Weiss i in. (2006) twierdzą, że agresywne i impulsywne zachowanie, które prowadzi do kryminalnych i antyspołecznych zachowań może być produktem defektu regulacji emocji, stąd szczególnie interesujące wydało się zróżnicowanie w zakresie inteligencji emocjonalnej, oraz przyczyny tego zróżnicowania. Przeprowadzone badania i potwierdzenie hipotezy, iż istnieje różnica w poziomie inteligencji emocjonalnej skazanych i nieskazanych, mogą być bazą dla badań z zakresu neuropsychologii czy kryminologii, które będą miały na celu ustalenie przyczyn defektu kompetencji emocjonalnej u przestępców. 
Badania zostały przeprowadzone o ile to możliwe zgodnie $\mathrm{z}$ prawidłami badań psychologicznych (Brzeziński, 2004). Jednak pewnych niedociągnięć nie udało się uniknąć. Jednym z nich jest zły dobór próby - warunki Zakładu Karnego uniemożliwiły dobór próby w sposób najbardziej wskazany metodologicznie, czyli losowy. Zbierając osoby do badań udało się nakłonić grupę najłatwiej dostępną - skazanych którzy dysponowali czasem wolnym, $\mathrm{z}$ jakichś przyczyn odczuli potrzebę uczestniczenia $\mathrm{w}$ badaniu, nie uznawali ideologicznych przeciwwskazań. Do części skazanych, która wydaje się istotna z perspektywy przeprowadzonych badań, nie było dostępu właśnie ze względu na wyznawane przekonania - mowa tu o więźniach grypsujących. Udział w badaniach był przez tą grupę więźniów postrzegany jako współpraca z administracją, a jak twierdzi Kamiński (2006) zasada odmowy przestrzegana wśród grypsujących polega na zakazie dobrowolnej współpracy z administracją, chyba, że przynosi korzyść. Prawdopodobnie skazani grypsujący uznali brak korzyści w udziale w badaniu. Odchodząc od przyczyn niechęci wzięcia udziału w badaniach, ze względu na brak w próbie więźniów grypsujących, próba nie okazała się reprezentatywna.

Drugim zagadnieniem na które chciałem zwrócić uwagę jest standaryzacja. Jak wiadomo, by wyniki danego testu można było ze sobą porównywać, dany test powinien być zawsze przeprowadzony $\mathrm{w}$ identycznych warunkach, bowiem wtedy można różnice w wynikach testowych badanych osób przypisać czynnikom indywidualnym badanych, a nie czynnikom zewnętrznym badania. Takie warunki, w miarę możliwości moich i instytucji w której były prowadzone badania, starałem się stworzyć - wszyscy badani otrzymali wyjaśnienie celu badania i instrukcję wypełniania testu, test był wypełniany $\mathrm{w}$ oddzielnym pomieszczeniu, w towarzystwie dwóch innych wypełniających. Wymogi standaryzacji wskazywałyby raczej na indywidualne wypełnianie testu, lecz ze względu na czasochłonność przekraczającą czas jaki administracja Zakładu Karnego wyznaczyła mi na przeprowadzenie badań oraz niedostępność próby w inny sposób, zdecydowano o przeprowadzeniu badań w powyższej formie.

Niezrozumienie instrukcji, czy wadliwe wypełnienie arkusza testowego również mogło wpłynąć na otrzymane wyniki badań. Pomimo instrukcji pisemnej niektórzy badani mieli problem z jej zrozumieniem. Utrudnienia, które się pojawiały to zaznaczanie wyłącznie jednej emocji w Skali Inteligencji Emocjonalnej, którą rozpoznał badany (co było korygowane poprzez wskazanie, iż wszystkie pola muszą zostać wypełnione), czy nieznajomość nazw niektórych emocji, ze szczególnym wskazaniem na określenie 
„kokieteria” (terminy były wyjaśniane przez badającego możliwie najbardziej znanym określeniem bliskoznacznym - we wskazanym przypadku była to „zalotność”). Pomijanie odpowiedzi zdarzało się często, ale podlegało korygowaniu.

Należy zdać sobie sprawę, co do ograniczeń wynikających z generalizacji wniosków uzyskanych z przeprowadzonych badań. Nie można ich odnieść do wszystkich skazanych, ponieważ przeprowadzone badania objęły grupę 50 przestępców. Z pewnością nie można odnieść wniosków do całej populacji przestępców - nie da się przebadać przestępców nieskazanych, gdyż z powodu zagrożeń procesowych nie ujawniają się, a nawet jeśli $\mathrm{z}$ pewnością nie wyrażą zgody na udział $\mathrm{w}$ badaniach $\mathrm{w}$ odpowiednio licznej próbie. Dodatkowo sama próba przeprowadzenia badań mogłaby być niebezpieczna dla badającego. Przestępcy jako grupa społeczna są bowiem prawdopodobnie najbardziej skłonni do używania agresji. Możliwość przeprowadzenia badań zgodnych z wszystkimi prawidłami metodologii badań psychologicznych o których mówi Brzeziński (2004) w kwestii doboru próby jest znikoma. Kontynuując badania, należałoby zebrać liczniejszą grupę badanych, a także objąć nią cały przekrój przestępców. Można oczywiście pójść drogą wyznaczoną przez Gierowskiego (2005) twierdzi on, że w odniesieniu do właściwości temperamentalnych człowieka i związku z ogólniejszą tendencją do łamania prawa, nie ma prostych zależności. Można takie zauważyć, dopiero, gdy wprowadzi się typologie sprawców, uwzględniającą charakter popełnianych czynów, ich okoliczności, i zmienne motywacyjne. Zawężając próbę do określonej grupy przestępców, otrzymane wyniki prawdopodobnie będą bliższe stanowi rzeczywistemu.

$\mathrm{Z}$ perspektywy psychologii przestępca jest to człowiek, taki jak nie przestępca. Jest to osoba, która ze względu na swoje właściwości osobowościowe oraz sytuację w której się znalazła uruchomiła motywację, prowadzącą do celu, łamiąc zasady porządku społecznego, na których straży stoi prawo. Osoba ta może cechować się zmianami osobowościowymi typu psychopatycznego, wyróżniać się odchyleniem charakterologicznym na polu systemu wartości, której, właściwie funkcjonujący układ nerwowy może sprzyjać niewłaściwym, w tym i przestępczym formom zachowania. Może też charakteryzować się niższym od średniej ilorazem inteligencji. Wreszcie na ukształtowanie się osobowości przestępcy, co udowodniono, niebagatelny wpływ ma negatywny kontakt $\mathrm{z}$ innymi osobami i towarzyszące temu napięcia. Kolejnym czynnikiem różnicującym przestępców od reszty populacji może być, na co wskazują wyniki przeprowadzonych badań poziom inteligencji emocjonalnej. 


\section{Literatura cytowana}

Batawia, S. (1984). Wstęp do nauki o przestępcy. Wrocław-Warszawa-Gdańsk-Kraków: Zakład Narodowy im. Ossolińskich - Wydawnictwo Polskiej Akademii Nauk.

Błachut, J., Gaberle, A., Krajewski, K. (2007). Kryminologia. Gdańsk: Wydawnictwo Arche.

Brzeziński, J. (2004). Metodologia badań psychologicznych. Warszawa: PWN.

Ekman, P. (2003). Unmasking the face. A guide to recognizing emotions from facial expressions. Los Altos CA: Malor Books.

Gierowski, J. K. (2005). Psychologiczne wyznaczniki przestępczości. W: J. Strelau (red.), Psychologia. Podręcznik akademicki, Tom III. Jednostka w spoteczeństwie i elementy psychologii stosowanej (s. 710-729). Gdańsk: Gdańskie Wydawnictwo Psychologiczne.

Gross, N. R., Morgan, R. D. (2013). Understanding Persons With Mental Illness Who Are and Are Not Criminal Justice Involved: A Comparison of Criminal Thinking and Psychiatric Symptoms. Law and Human Behavior, 37, 175-186.

Herrnstein, R. J., Muray, C. (1994). The Bell Curve. Intelligence and Class Structure in American Life. Nowy Jork - Londyn - Toronto - Sydney - Tokio - Singapur: The Free Press.

Iria, C., Bartosa, F. (2009). Perception of facial expressions of fear: comparative research with criminal and non-criminal psychopaths. The Journal of Forensic Psychiatry \& Psychology, 20, 66-73.

Kosewska, A., Kosewski, M. (1976). Osobowościowe czynniki zachowań dewiacyjnych. W: A. Podgórecki (red.), Zagadnienia patologii społecznej. Warszawa: PWN.

Matczak, A., Piekarska, J., Studniarek, E. (2005). Skala Inteligencji Emocjonalnej- Twarze. Pordęcznik. Warszawa: Pracownia Testów Psychologicznych Polskiego Towarzystwa Psychologicznego.

Mayer, J., D., Salovey, P., Caruso, D., R. (2004). Emotional Intelligence: Theory, Findings, and Implications. Psychological Inquiry, 15, s. 197-215.

Ustawa z dnia 6 czerwca 1997 r. - Kodeks karny wykonawczy (Dz. U. nr 90, poz. 557 z późn. $\mathrm{zm}$.).

Włodawiec, B. (2013). Zastosowanie kwestionariusza SCL-90 w badaniach nad efektywnościa psychoterapii. Pozyskano z :

http://www.psychologia.net.pl/artykul.php?level=298

Weiss, E. M. i in. (2006). The Relationship Between History of Violent and Criminal Behavior and Recognition of Facial Expression of Emotions in Men with Schizophrenia and Schizoaffective Disorder, Aggressive Behavior, 32, 187-194. 